\title{
Pendidikan Literasi pada Pembelajaran Kitab Kuning di Pondok Pesantren Nurul Huda Sukaraja
}

\author{
Lailatul Fitriyah ${ }^{1}$, Marlina $^{2}$, dan Suryani ${ }^{3}$ \\ ${ }_{123}$ STKIP Nurul Huda \\ E-mail: lailatul@stkipnurulhuda.ac.id11,marlina@stkipnurulhuda.ac.id², suryani@stkipnurulhuda.ac.id³
}

\begin{abstract}
Abstrak
Penelitian ini bertujuan mendeskripsikan pendidikan literasi pada pembelajaran kitab kuning di pondok pesantren Nurul Huda. Teori yang digunakan adalah teori literasi Tylaar bahwa literasi meliputi empat ketrampilan berbahasa. Metode dalam penelitian ini adalah metode deskriptif kualitatif berupa studi kasus. Teknik pengumpulan data dalam penelitian ini adalah wawancara, observasi, dan dokumentasi. Pendidikan literasi di pontren tercermin dalam lima metode pembelajaran yaitu; makanani (terjemahan tatabahasa), bandongan (memaknai teks dengan panduan guru secara bersama-sama/kelompok besar), sorogan (presentasi individu terkait suatu materi), musyawarah (diskusi), dan muhafadoh (hafalan).
\end{abstract}

Kata kunci: Pendidikan Literasi, Kitab Kuning, Pondok Pesantren.

\section{PENDAHULUAN}

Salah satu yang sangat menarik dari beberapa istilah pendidikan yang muncul belakangan adalah pendidikan literasi. Pendidikan literasi menjadi penting, sebab pengesampingan terhadap literasi akan berdampak pada pembentukan kecenderungan siswa yang gemar membeo pada pengetahuan tertentu yang diyakininya benar dan menutup kemungkinan akan kebenaran yang lain. pendidikan literasi diharapkan mampu menjawab persoalan yang muncul akibat rendahnya minat baca siswa. Survei UNESCO pada 2012 menunjukkan bahwa indeks membaca masyarakat Indonesia adalah 0,001 . Artinya setiap 1000 penduduk hanya satu orang yang memiliki minat baca. Hasil tes Proggrammefor International Student Assesment (PISA) pada tahun yang sama tentang literasi matematika, membaca, dan sains menempatkan Indonesia pada urutan 64 dari 65 negara yang disurvei. Selain itu, skor literasi membaca siswa Indonesia (usia 15 tahun) hanya 396, jauh di bawah standar rata-rata 496. Alasan lain yang kemudian juga menjadikan literasi itu penting adalah bahwa literasi menjadi salah satu kecakapan yang harus dikuasi untuk menghadapi abad 21, di samping kecakapan kompetensi dan karakter. Ini sebagaimana laporan yang dikeluarkan oleh Forum Ekonomi Dunia (World Economic Forum-WEF) pada 2015 mengenai keterampilan yang harus dimiliki untuk menghadapi abad 21. Keterampilan itu mencakup literasi, kompetensi, dan karakter (Antoro,2017:5).

Selain itu, ada beberapa hal yang menurut penulis penting untuk menganggap bahwa pendidikan literasi itu penting. Pertama, bahwa dengan pendidikan literasi orang jadi melek terhadap informasi yang kemudain akan berimbas pada peningkatan kualitas SDM. kedua, bahwa pendidikan literasi memungkin bagi orang untuk menyampaikan kebenaran dalam skala yang luas. Ketiga, dengan pendidikan literasi, sangat mungkin seseorang mempengaruhi orang lain di sekitarnya, bahkan orang yang tidak dikenalnya sekalipun. Hal-hal tersebut sangat mungkin, sebab literasi berkaitan erat dengan komunikasi. Kern (2000) menyatakan bahwa "Literacy involves commucation" (literasi melibatkan komunikasi). Karena itulah, literasi meliputi keaksaraan dan kewicaraan atau lisan dan tulisan.

Literasi berasal dari bahasa Latin literatu yang berarti orang yang belajar. Secara tradisional, literasi dipandang sebagai kemampuan membaca dan menulis. Dalam perkembangannya literasi dimaknai sebagai kemampuan menyimak, berbicara, membaca, dan menulis (Abidin, 2017:1). Dalam konsep literasi, membaca diartikan sebagai usaha untuk memahami, menggunakan, merefleksi, dan melibatkan berbagai jenis teks untuk mencapai tujuan (Abidin, 2017:165). Menyimak dalam literasi dimaksudkan untuk memperluas wawasan dan pengetahuan. Keterampilan menyimak dapat menjadi 
cara untuk memahami lebih mendalam informasi yang berkembang. Kemampuan menulis dimaksudkan sebagai kemampuan dalam menuangkan dan mengkomunikasikan ide dan gagasan kepada orang lain. Sedangkan kemampuan berbicara berkaitan dengan kemampuan dalam memproduksi gagasan secara lisan dengan isi yang berkualitas dan cara yang tepat.

Dengan demikian, literasi identik dengan kemampuan berbahasa secara menyeluruh, yaitu kemampuan menyimak, berbicara, membaca, dan menulis. Seseorang dapat dikatakan literate, yang secara luas dapat diartikan terdidik, jika ia menguasai keempat keterampilan berbahasa tersebut sekaligus. Karenanya, kemampuan literasi harus menjadi jantung dari seluruh proses pendidikan (Tilaar, dkk, 2011:196). Dengan demikian pendidikan literasi dapat diartikan sebagai pendidikan yang menerapkan keseluruhan keterampilan berbahasa dalam proses pembelajarannya untuk mendapatkan hasil yang maksimal.

Wells (1987) menyebutkan empat tingkatan literasi, yaitu performative, functional, informational, dan epistemic. Pada tingkat performative, kemampuan literasi yang dimiliki seseorang adalah membaca dan menulis serta berbicara dengan simbol-simbol yang digunakan (bahasa). Ini merupakan tingkatan literasi yang paling dasar. Pada tingkat functional, orang diharapkan mampu menggunakan bahasa untuk memenuhi kebutuhan sehari-hari. Pada tingkat informational, orang diharapkan dapat mengakses pengetahuan. Dan pada tingkat epstemic, orang diharapkan dapat mentransformasikan pengetahuan yang dimilikinya.

Ada sejumlah persyaratan untuk menjadikan literasi sebagai jantung dalam proses pendidikan (mewujudkan pendidikan literasi). Pertama, keberadaan guru-guru yang memiliki keterampilan berbahasa. Kedua, daftar dan ketersediaan buku-buku. Ketiga, ada jadwal dan waktu yang memadai untuk melaksanakan program tersebut (Tilaar, dkk, 2011:197). Persyaratan tersebut tentu tidak mudah, mengingat bahwa tidak semua guru menguasai keterampilan berbahasa. Belum lagi persoalan bahwa pada kenyataannya tidak semua guru bahasa Indonesia (yang umumnya sarjana pendidikan bahasa Indonesia) dapat dipastikan memiliki kompetensi berbahasa Indonesia yang baik. Banyak faktor yang menjadi latar belakang kondisi tersebut. Di samping itu, Kern (2000) menjelaskan bahwa pembelajaran literasi memiliki ciri 3R, yaitu Responding, Revising, dan Reflecting. Responding berkaitan dengan respon baik dari pihak siswa maupun dari pihak guru. Respon siswa berkaitan dengan tugas yang diberikan dan teks yang dibacanya. Respon guru berkaitan dengan bagaimana guru merspon jawaban siswa agar siswa dapat mencapai pemahaman yang diharapkan. Termasuk juga respon guru, adalah respon terhadap hasil dari tugas siswa. Revising meliputi berbagai aktifitas berbahasa, yang dimaksudkan di sini adalah merevisi. Sedangkan Reflecting berkaitan dengan evaluasi terhadap semua komponen dalam proses pembelajaran.

Sejatinya pendidikan literasi dapat ditemukan penerapannya di hampir semua bidang pendidikan tanpa terkecuali pendidikan di pondok pesantren. Pendidikan di pondok pesantren yang sumber utama pembelajarannya adalah kitab kuning sangat kental dengan tradisi literasi. Hal ini bisa dilihat dari posisi ilmu bahasa yang mendapat tempat begitu terhormat di pondok pesantren mengingat fungsinya sebagai kunci bagi kelancaran studi kitab kuning. Bagaimana tidak, sebagai literatur universal klasik, kitab kuning amat membutuhkan ilmu bahasa sebagai pengantar studi terhadapnya.

Pesantren merupakan institusi pendidikan yang berada di bawah pimpinan seorang atau beberapa kiai dan dibantu oleh sejumlah santri senior serta beberapa anggota keluarganya. Pesantren menjadi bagian yang sangat penting bagi kehidupan kiai sebab ia merupakan tempat bagi kiai untuk mengembangkan dan melestarikan ajaran, tradisi, dan pengaruhnya di masyarakat. Tujuan pendidikan pesantren adalah membentuk manusia yang memiliki kesadaran yang tinggi bahwa ajaran Islam bersifat komprehensif. Selain itu, produk pesantren juga dikonstruksi untuk memiliki kemampuan yang tinggi dalam merespon tantangan dan tuntutan hidup dalam konteks ruang dan waktu, dan dalam ranah nasional maupun internasional. Alasan pokok munculnya pesantren sebagai penyelenggara pengajaran agama Islam adalah untuk mentransmisikan Islam tradisional sebagaimana terdapat pada kitab-kitab klasik yang ditulis berabad-abad yang lalu (kitab kuning) (Bruinessen, 2012:89).

Pesantren dengan kitab kuning laksana dua sisi mata uang yang tidak dapat dipisahkan. Tidak 
ada pesantren tanpa pengajian kitab kuning. Kitab kuning menjadi unsur sekaligus ciri khas pesantren. Pesantren dengan kitab kuningnya telah menjadi semacam instrumen bagi perubahan dan perkembangan masyarakat Indonesia. Disebabkan oleh belajar kitab kuning, ulama-ulama Indonesia menghabiskan banyak waktu di Makkah, Madinah, dan pusat-pusat pengajaran Islam di Timur Tengah. Dengan pembelajaran kitab kuning pula pembelajaran pesantren yang khas Indonesia mewujud. Tradisi pondok (mondok di) pesantren ini misalnya. Bahwa pondok pesantren merupakan lembaga khas Indonesia ini dikuatkan oleh pendapat Martin Van Bruinessen (2012:90) berikut "Pondok pesantren bisa dianggap lembaga yang khas pesantren. Meskipun ia merupakan lembaga pendidikan Islam tradisional, namun dalam beberapa aspek, berbeda dengan sekolah tradisional di dunia Islam manapun. Di sisi lain, pada saat yang sama ia berorientasi internasional, dengan Makkah sebagai pusat orientasinya, bukan Indonesia."

Kitab kuning adalah kumpulan hasil pemikiran para ulama terdahulu. Hal ini sejalan dengan pendapat berikut. "Secara umum kitab kuning dipahami oleh beberapa kalangan sebagai kitab referensi keagamaan yang merupakan produk pemikiran para ulama pada masa lampau yang ditulis dengan format khas pra-modern, sebelum abad ke-17-an M."(PD Pontren, 2008:95). Kitab kuning merujuk pada sehimpunan kitab yang berisi pelajaran-pelajaran agama Islam (diraasahallslamiyyah) hingga ilmu sosial dan kemasyarakatan lainnya. Kitab kuning juga merupakan salah satu unsur penting dalam kehidupan pesantren. Apa yang disebut dengan tradisi pesantren tidak bisa dilepaskan dari kedudukan penting pengajaran dan pembelajaran kitab kuning (Bruinessen, 2012:v)

Istilah kitab kuning pada mulanya diperkenalkan oleh kalangan luar pesantren dengan nada merendahkan. Dalam pandangan mereka kitab kuning dianggap sebagai kitab yang berkadar rendah, ketinggalan zaman bahkan menjadi penyebab terjadinya stagnasi pemikiran umat. Penyebutan ini pada awalnya sangat menyakitkan, tetapi kemudian nama kitab kuning diterima secara luas sebagai salah satu istilah teknis dalam studi kepesantrenan (Wahid dkk, 1999:221-222). Disebut kitab kuning karena kitab-kitab tersebut dicetak di atas kertas berwarna kuning, meskipun kemudian dicetak ulang pada kertas putih. Kitab ini ditulis dengan menggunakan aksara arab dan berbahasa Arab. Sehingga, untuk memahaminya memerlukan penguasaan terhadap bahasa Arab berikut tata bahasanya secara mendalam.

Nama lain dari kitab kuning adalah kitab klasik atau kitab kuno dan karena hurufnya tidak memiliki harkat sering pula disebut kitab Gundul (Azra, 2001:37). Isi dari kitab kuning selalu terdiri dari dua komponen yaitu, komponen matan/teks asal dan komponen sarah/teks penjelas (Raharjo, 1985:55). Seiring dengan perkembangan zaman kitab kuning tidak harus dicetak dengan kertas berwarna kuning dan bacaannya dapat disertai dengan tanda baca atau harokat agar lebih mudah untuk dipelajari.

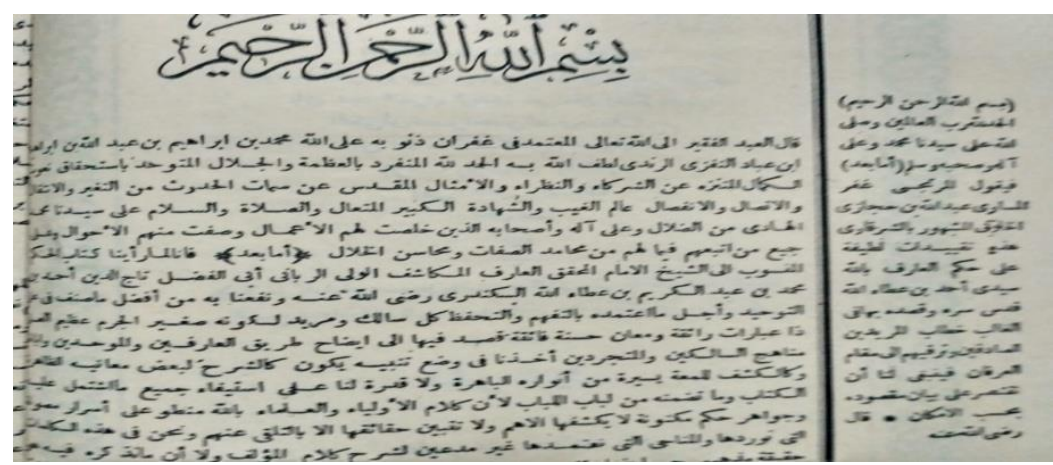

Gambar 1, Contoh Teks Kitab Kuning

Ada dua metode yang berkembang di lingkungan pesantren terkait cara mempelajari kitab kuning, yaitu metode sorogan dan metode bandongan. Metode sorogan dilaksanakan dengan cara santri membaca kitab kuning di hadapan ustadz atau kiai yang langsung menyaksikan keabsahan bacaan santri, baik dalam konteks makna maupun bahasa (nahwu dan shorf). Metode kedua pada prakteknya, santri secara kolektif mendengarkan bacaan dan penjelasan sang kiai atau ustadz sambil masing-masing memberikan catatan pada kitabnya. Catatan tersebut dapat berupa syakl atau makna 
mufrodat atau penjelasan (keterangan tambahan). Dalam membaca teks kitab kuning, metode yang umum digunakan di kalangan pesantren adalah metode utawiikiiku, cara membaca dengan pendekatan tata bahasa (nahwu dan shorf) yang ketat. Selain kedua metode tersebut, belakangan berkembang metode jalsah (diskusi partisipatoris) dan halaqoh (seminar). Kedua metode ini lebih sering di gunakan oleh para kiai untuk membahas isu-isu kontemporer dengan bahan pemikiran yang bersumber dari kitab kuning (Matraji', 2008:96).

Salah satu pesantren yang juga menerapkan pembelajaran kitab kuning adalah pondok pesantren Nurul Huda Sukaraja. Pesantren Nurul Huda Sukaraja terletak di wilayah kabupaten OKU Timur Sumatera Selatan, tepatnya di desa Sukaraja Kecamatan Buay Madang. Pesantren ini berdiri pada pertengahan tahun 80 -an, tepatnya di bulan September, atas prakarsa masyarakat desa Sukaraja yang dimotori oleh $\mathrm{KH}$. Affandi dengan dukungan para sesepuh desa.Saat ini pondok pesantren Nurul Huda Sukaraja memiliki sekiatar 3.400 santri (PD Pontren) yang tersebar pada berbagai unit pendidikan mulai dari tingkat taman kanak-kanak (RA/Roudlotul Athfal) hingga level perguruan tinggi (STKIP $\mathrm{NH} /$ Sekolah Tinggi Keguruan dan IImu Pendidikan Nurul Huda). Pondok pesantren ini menyelenggarakan model pendidikan Salafiah plus, yaitu penyelenggaraan pendidikan yang mengintegrasikan pendidikan salafiyah (diniyah) dengan pendidikan modern (madrasah) (Mardiansyah, 2017:110). Pesantren ini menyelenggarakan pendidikan formal mulai dari tingkat TK/RA sampai tingkat perguruan tinggi. Pendidikan informal diselenggarakan mulai dari madrasah diniyahibtidaiyah hingga madrasah diniyahaly (ma'had 'aly). Sedangkan pendidikan nonformal diselenggarakan di asrama-asrama dalam bentuk pengajian/pembelajaran kitab kuning, pembelajaran kemandirian, berinteraksi sosial, dan lain-lain.

\section{METODE}

Penelitian ini merupakan penelitian dengan metode studi kasus. Basuki mengatakan bahwa studi kasus merupakan kajian mendalam tentang peristiwa, lingkungan, dan situasi tertentu yang memungkinkan mengungkapkan atau memahami sesuatu hal (Prastowo, 2011:129). Dalam penelitian ini, sesuatu yang akan dikaji secara mendalam adalah situasi atau proses pembelajaran kitab kuning. Studi kasus merupakan jenis penelitian yang masuk dalam kelompok penelitian deskriptif (Prastowo:2011). Studi kasus digunakan ketika peneliti ingin menjawab pertanyaan deskriptif (apa yang terjadi) atau pertanyaan penjelasan (bagaimana/kenapa sesuatu itu terjadi)(Gay, dkk, 2012:445). Pertanyaan deskriptif yang hendak dijawab dalam penelitian ini adalah pendidikan literasi.

Penelitian ini dilaksanakan di salah satu unit pada Pesantren Nurul Huda Sukaraja. Data-data dikumpulkan dengan cara wawancara, observasi, dan dokumentasi. Cara-cara tersebut diterapkan karena data-data yang menjadi kebutuhan penelitian ini adalah informasi tentang keseluruhan proses pembelajaran kitab kuning, dan hal-hal yang mendukung proses pembelajaran. Yin menjelaskan bahwa ada enam sumber bukti yang dapat dijadikan fokus bagi pengumpulan data studi kasus, yaitu dokumen, rekaman arsip, wawancara, observasi langsung, observasi pemeran serta, dan perangkat fisik (Prastowo, 2011:139).

\section{HASIL DAN PEMBAHASAN}

\section{Pembelajaran Kitab Kuning pada Madrasah Diniyah Takhasus Aliyah (MDTA) al Umami}

Dalam pembelajaran, masuk di dalamnya adalah metode yang digunakan, guru sebagai pengajar, media yang digunakan, dan jadwal pembelajaran.

\section{a. Metode pembelajaran}

Metode pembelajaran merupakan cara yang digunakan oleh guru untuk menyampaikan materi kepada peserta didik dalam kegiatan belajar mengajar. Secara umum, pesantren memiliki beberapa macam metode yang digunakan dalam kegiatan pembelajaran kitab kuning. Berikut ini metode yang digunakan dalam kegiatan pembelajaran kitab kuning di MDT Aliyah al Umami.

\section{Maknani (Terjemahan)}

Yang dimaksudkan dengan metode maknani adalah guru membacakan teks kitab kuning dan mengartikannya, kemudian menjelaskan maksud teks tersebut, sedangkan santri menuliskan arti 
teks tersebut sebagaimana pemaknaan guru. Santri mendengarkan penjelasan guru, dan mencatat penjelasan-penjelasan penting yang disampaikan oleh guru. Metode pembelajaran seperti ini dilakukan dalam pembelajaran di kelas (klasikal) pada pelajaran-pelajaran seperti Nahwu, Shorf, Tafsir, Hadits, Fiqih, Tauhid, dan Akhlak.

Dalam pelaksanaan metode ini, ketika memaknai, santri tidak bisa lepas dari pengkodean untuk memahami kedudukan kata per kata dalam struktur kalimat. Misalnya kode $\mathrm{Fa} \mathrm{(} \mathrm{ف} \mathrm{)} \mathrm{sebagai}$ penanda pelaku tidak berakal, kode Faa ( ا ا ) sebagai penanda pelaku berakal. Demikian seterusnya. Untuk memudahkan santri menghafalkan kode-kode tersebut, guru menyiapkan materi yang khusus untuk itu berupa lembaran yang bernama Kaifiyatul Ma'anibiallkhtishor. Selain itu, untuk membantu santri agar mudah dalam memahami tata bahasa Arab, guru menyiapkan lembaran yang berisi ringkasan materi tata bahasa Arab yang bernama Jadwal an Nahwual Awwal, ats Tsani, dan ats Tsalits.

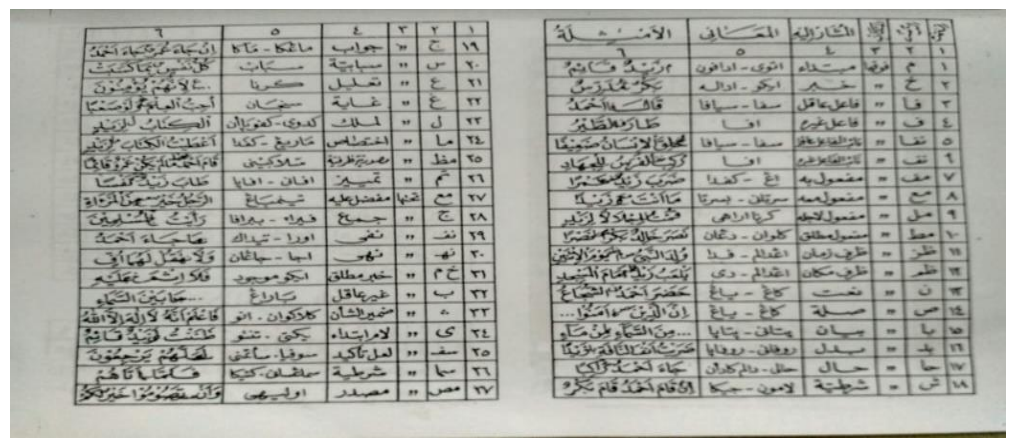

Gambar 2, Sistem Pengkodean dalam Kitab Kuning

\section{Sorogan}

Pembelajaran kitab kuning dengan metode ini dilaksanakan dengan cara santri membacakan kembali teks yang telah dibaca oleh guru beserta tarkibnya (kedudukan/fungsi kata dalam kalimat) dan menjelaskan maksud teks tersebut. Metode ini dilaksanakan di awal atau di akhir pembelajaran. Dilaksanakan di awal pembelajaran dengan maksud mereview (mengulang) pelajaran yang telah disampaikan pada pertemuan sebelumnya. Pelaksanaan metode ini di akhir pembelajaran bertujuan untuk melihat seberapa baik penyerapan santri terhadap pelajaran yang telah disampaikan guru. Metode ini dilaksanakan pada pembelajaran untuk pelajaran-pelajaran seperti pada metode Maknani.

Pada praktek pembelajaran seperti ini, bisa terjadi guru telah menyampaikan kepada santri agar mempersiapkan materi tertentu baik segi kebahasaan maupun penjelasannya pada pertemuan sebelumnya untuk kemudian dipresentasikan pada pertemuan selanjutnya. Santri yang mendapatkan jatah untuk presentasi adalah santri yang ditunjuk oleh guru secara acak. Dalam hal ini masing-masing santri secara mandiri dituntut untuk memahmi teks yang telah ditentukan oleh guru.

Dalam pembelajaran dengan metode ini dapat terjadi dialog antara guru dan santri yang biasanya dimulai dari koreksi guru terhadap bacaan santri. Selain mengoreksi bacaan murid, guru juga akan menguji pemahaman santri dengan cara meminta santri menerangkan kembali maksud dari teks yang telah dibacanya. Pembacaan santri terhadap teks meliputi membaca dengan menerapkan gramatika dan membaca dengan memaknai teks dan menjelaskan maksudnya. Pada pembelajaran dengan metode ini, santri tidak hanya dituntut benar-benar tuntas menguasai teknik pembacaan tetapi juga benar-benar tuntas menguasai materi pembahasan. Metode ini tidak hanya membuat santri mampu membaca teks kitab kuning yang serba Arab, tetapi juga memungkinkan baginya untuk kitab-kitab lain yang secara tematik memiliki pembahasan yang sama dengan teks yang dibaca.

\section{Bandongan/Wetonan}

Metode ini dilaksanakan dengan cara kiai membacakan teks kitab kuning dan membacakan artinya dihadapan semua santri dari semua kelas (kelas besar). Sementara itu, santri menuliskan arti kata 
perkata sebagaimana arti yang disampaikan oleh kiai. Dalam metode ini, tidak jarang guru menjelaskan maksud dari teks yang dibaca secara panjang lebar, termasuk juga kiai menjelaskan aspek tata bahasa (tarkib) dari teks yang dibaca. Dalam metode ini, tidak jarang kiai memasukkan cerita-cerita yang sifatnya memotivasi santri atau cerita-cerita teladan yang bersumber dari kisahkisah Rosul, Shohabat, kisah-kisah teladan, atau bahkan kisah kiai sendiri.

\section{Musyawarah (diskusi)}

Pada kegiatan ini, santri (siswa) menunjuk ketua kelompok sebagai pemimpin diskusi. Jika musyawarah ini dalam tingkatan kelas, maka musyawarah dimaksudkan untuk mendiskusikan materi pelajaran yang sudah dipelajari. Pada kegiatan pembelajaran ini, santri (siswa) dilatih beradu argumentasi dengan merujuk pada kitab-kitab yang telah dipelajari atau kitab-kitab lain yang memungkinkan bagi mereka untuk membacanya.

Metode pembelajaran kitab kuning yang seperti ini melatih seluruh keterampilan berbahasa santri; mulai dari menyimak, berbicara, membaca, dan menulis. Latihan menyimak terjadi ketika santri mendengarkan apa yang disampaikan oleh teman diskusi yang lain. Latihan berbicara terjadi ketika santri menyampaikan argumentasinya. Latihan membaca terjadi ketika santri membaca dan menelaah teks-teks yang menjadi rujukan dalam pembahasan masalah.

\section{Muhafadhoh (Hafalan)}

Metode ini digunakan untuk mempermudah santri dalam mengingat materi pelajaran, terutama pelajaran yang berkaitan dengan tata bahasa/kaidah bahasa Arab (Nahwu dan Shorf). Metode ini dilakukan dengan cara santri menghafal materi pelajaran yang berwujud syair (nadhom), yaitu nadhom Alfiyah Ibnu Malik. Nadhom ini berisi kaidah-kaidah dalam bahasa Arab, seperti tentang aturan pembacaan kata apakah akan dibaca dlomah, fatkhah, atau kasroh. Atau juga tentang definisi subjek, objek, kata kerja, atau kata benda, dan lain-lain. Untuk memudahkan dalam menghafal, santri biasanya melakukan lalaran terhadap syair (nadhom) yang akan dihafalkan. Melalui lalaran (pembiasaan membaca dengan dilagukan) santri dengan sendirinya akan hafal terhadap apa yang dibacanya.

\section{b. Guru}

Guru yang menjadi tenaga pengajar di MDTA al Umami sejumlah 15 guru. Dari 15 guru tersebut, tujuh di antaranya adalah alumni pondok pesantren Lirboyo Kediri Jawa Timur. Satu orang alumni Daarul Mustofa Yaman, satu di antaranya alumni Ma'had Aly Nurul Huda, dan enam di antaranya alumni MDTA al Umami.

Alumni pondok pesantren Lirboyo Kediri Jawa Timur yang menjadi tenaga pengajar adalah mereka yang telah menyelesaikan pendidikan pada madrasah diniyah di pesantren tersebut pada level yang paling tinggi. Secara keilmuan, terutama ilmu tata bahasa Arab, alumni pesantren ini tidak diragukan lagi. Ini menjadi jaminan bahwa guru-guru di MDTA al Umami memiliki kompetensi kebahasaan (bahasa Arab) yang baik. Selain itu, adalah jaminan bahwa mereka memiliki pemahaman yang baik terhadap teks kitab kuning yang di pelajari.

Latar belakang guru yang alumni Lirboyo memungkinkan untuk terwujudnya pembelajaran kitab kuning yang berkualitas. Bagaimana tidak, guru-guru tersebut telah ditempa sedemikian rupa pada saat menuntut ilmu di pesantren Lirboyo. Pembelajaran kitab kuning yang secara bandongan terjadi lebih dari dua kali dalam sehari, sorogan dengan tuntutan yang tinggi terhadap pemahaman teks kitab kuning baik dari segi kebahasaan maupun penjelasan, diskusi yang dilaksanakan secara berkala dengan tertib dan dengan argumentasi yang berdasar kuat, juga tradisi hafalan yang demikian kuat, menjadi jaminan akan kualitas alumni Lirboyo. Proses pembelajaran kitab kuning yang demikian ketat mengasah kemampuan berbahasa Arab, terutama aspek menyimak, membaca, dan menulis. Sedangkan aspek berbicara dapat dikatakan kurang. Ini karena memang basis pembelajaran adalah pemahaman terhadap teks kitab kuning.

Secara keseluruhan, keberadaan guru yang menjadi tenaga pengajar telah dapat dikatakan memiliki keterampilan berbahasa Arab yang cukup baik. Keterampilan berbahasa Arab ini berkaitan 
dengan keterampilan membaca, menyimak, dan menulis. Kompetensi kebahasaan ini yang memang diperlukan dalam pembelajaran kitab kuning.

\section{c. Media}

Media utama yang digunakan pada pembelajaran kitab kuning di MDTA al Umami adalah bukubuku yang berupa teks kitab kuning dalam jumlah yang memadai. Termasuk di dalamnya kamus Bahasa Arab yang menjadi penunjang dalam memahami teks kitab kuning, dan buku-buku terjemahan sebagai media pembanding. Selain itu, ada jadwal Nahwu satu sampai tiga (materi untuk memahami kalimat). Selain jadwal nahwu, ada juga jadwal yang memuat sistem pengkodean dalam mamaknai teks kitab kuning.

Ada sekitar 150 judul buku dan kitab kuning yang tersedia dan digunakan pada MDTA al Umami, baik digunakan sebagai referensi utama pada pembelajaran (kitab pegangan guru), maupun sebagai referensi tambahan. Buku-buku dan kitab-kitab tersebut meliputi materi tata bahasa, fiqih, tasawuf, sejarah, akhlak, hadits, tafsir, dan usul fiqih.

Ketersediaan kitab dan buku dalam jumlah yang memadai memungkinkan bagi santri untuk lebih maksimal dalam pembelajaran kitab kuning. Hal tersebut mewujud dalam beragamnya referensi yang dapat dibaca dan ditelaah. Di samping itu, pembacaan dan penelaahan terhadap buku-buku tersebut akan memperluas wawasan santri. Dalam hal ini, akan terbangun kebiasaan literasi santri berupa menyimak dan membaca.

\section{d. Jadwal pembelajaran}

Jadwal pembelajaran kitab kuning di MDTA al Umami meliputi jadwal sekolah diniyah formal, dan jadwal kegiatan harian. Jadwal sekolah formal dilaksanakan pada pagi dan sore hari. Jadwal pagi dimulai pada pukul 07.45 hingga pukul 10.15. jadwal sekolah sore dimulai pada pukul 14.30 hingga pukul 16.20. Jadwal pembelajaran sekolah diniyah formal meliputi materi-materi pokok pada kurikulum diniyah formal. Sementara jadwal harian memuat kegiatan harian yang dilaksanakan oleh santri. Termasuk dalam jadwal harian adalah jadwal pembelajaran kitab kuning di luar jadwal sekolah diniyah formal yang sifatnya penguatan terhadap pemahaman materi pada sekolah diniyah formal (pembelajaran tambahan).

Pembelajaran tambahan yang juga dijadwalkan dilaksanakan pada jam istirahat antara jadwal diniyah pagi dan sore, kegiatan pembelajaran malam hari, dan kegiatan pembelajaran pagi hari setelah subuh. Pembelajaran pada jam istirahat memuat pembelajaran bahasa Arab dan pembacaan teks kitab kuning dengan menggunakan metode modeling. Salah satu santri yang dianggap cakap ditunjuk untuk membaca teks kitab kuning di hadapan santri-santri yang lain, sementara guru mendengarkan dan mengoreksi bacaan santri.

Kegiatan pembelajaran pada malam hari dilaksanakan untuk menguatkan pemahaman santri terhadap teks kitab kuning. Kegiatan pembelajaran pada malam hari meliputi pengajian kitab kuning secara bandongan oleh kyai, sorogan kitab kuning, dan diskusi berkaitan dengan materi kitab kuning. Sementara kegiatan pembelajaran pada pagi setelah subuh lebih pada hafalan terhadap nadhom (bait puisi) yang berkaitan dengan materi dalam pembelajaran kitab kuning.

Secara keseluruhan proses pembelajaran kitab kuning di MDTA al Umami memiliki jadwal dan waktu yang memadai. Secara keseluruhan, santri mulai dari bangun tidur hingga tidur kembali berhadapan dengan teks kitab kuning, baik dalam bentuk prosa (natsr) maupun dalam bentuk puisi/syair (nadhom).

\section{Pendidikan Literasi pada Pembelajaran Kitab Kuning}

Pembelajaran kitab kuning di MDTA al Umami sebagaimana penjelasan pada sub judul di atas telah memenuhi persyaratan untuk dapat dikatakan bahwa pembelajaran kitab kuning pada MDTA al Umami telah menjadikan literasi sebagai jantung dalam proses pendidikan. Guru-guru yang memiliki komampuan berbahasa Arab yang baik, terutama kompetensi menyimak, membaca, dan menulis. Selian itu, ketersediaan buku dan kitab yang memadai yang menunjang proses pembelajaran, juga 
jadwal pembelajaran yang memadai yang memungkinkan proses pembelajaran dengan mempraktekkanliterasiberlansung dengan intensif.

Pendidikan literasi pada pembelajaran kitab kuning mewujud pada metode pembelajaran yang digunakan, yaitu maknani, sorogan, bandongan, diskusi (syawir), dan hafalan (muhafadhoh). Pada metode sorogan, santri dituntut memiliki kemampuan atau keterampilan menyimak yang baik, di samping juga kemampuan membaca dan berbicara. Keterampilan menyimak diperlukan untuk menyerap informasi berkaitan dengan penjelasan-penjelasan tentang teks kitab kuning yang akan dibaca dihadapan guru. Keterampilan membaca diperlukan untuk memahami (dengan cara maknani/memberi terjemahan) teks kitab kuning, baik pemahaman secara harfiyah maupun secara makna dan membacakan teks tersebut dihadapan guru. Keterampilan berbicara muncul ketika santri menjelaskan maksud dari teks yang dibaca.

Pada metode bandongan, ketrampilan atau kemampuan berbahasa yang paling penting adalah menyimak dan menulis (menulis tingkat dasar). Ketrampilan menyimak yang baik pada metode ini berkaitan dengan akurasi informasi yang diperoleh dari penyampaian guru termasuk akurasi dalam menuliskan makna pada teks kitab kuning yang dibaca oleh guru. Akurasi informasi dan akurasi dalam menuliskan kembali makna teks akan sangat berpengaruh pada akurasi pemahaman teks kitab kuning. Metode pembelajan ini merupakan metode pembelajaran tingkat tinggi dalam tradisi pesantren.

Pada pembelajaran dengan metode diskusi, keterampilan berbahasa yang kemudian dilatih dan harus dikuasia terutama adalah keterampilan berbicara (dalam hal ini berbicara dalam bahasa Indonesia) yang baik, termasuk di dalamnya menyusun pernyataan secara sistematis. Dalam diskusi diperlukan pemaparan argumentasi atas pendapat yang disampaikan. Argumentasi yang diungkapkan diperoleh dengan menerapkan kemampuan membaca dalam hal ini kemampuan membaca teks kitab kuning. Kemampuan membaca teks yang baik memungkinkan untuk membaca beragam referensi kitab kuning yang menjadi rujukan dalam diskusi. Sedangkan pada metode hafalan, keterampilan menyimak yang baik (secara detail) merupakan keterampilan berbahasa yang utama diperlukan. Kemampuan menyimak yang baik memungkinkan untuk mencapai hasil yang maksimal dalam hafalan. Termasuk dalam metode ini adalah kemampuan membaca (melafalkan) dengan baik dan benar.

Selain terwujud dalam lima metode pembelajaran tersebut, pendidikan literasi juga mewujud dalam empat bentuk pembelajaran. Lima metode ini mewujud dalam empat bentuk pembelajaran. Empat bentuk pembelajaran tersebut adalah sebagai berikut.

\section{Kegiatan Pembelajaran Inti}

Kegiatan pembelajaran inti merupakan kegiatan pembelajaran yang dilaksanakan santri secara klasikal (pembelajaran sesuai dengan kelas masing-masing). Pada kegiatan ini, pembelajaran diampu oleh ustadz yang disebut dengan mustahiq dan munawwib. Materi yang dibahas pada kegiatan pembelajaran inti meliputi materi nahwu, shorf, akhlaq, tasawuf, fiqih, ushulfiqih, hadits, dan lain-lain.

Pada kegiatan pembelajaran inti, ada kalanya ustadzdisamping menggunakan metode bandongan dan sorogan, diterapkan juga metode syawir (diskusi sederhana) dan muhafadhoh (hafalan). Biasanya, muhafadhoh dilaksanakan di awal pembelajaran begitu juga dengan syawir. Sementara sorogan dilaksanakan di akhir pembelajaran. Muhafadhoh yaitu menghafal bait-bait syair, bertujuan untuk memudahkan santri dalam mengingat kaidah-kaidah dalam tata bahasa Arab segi gramatika maupun pembentukan katanya. Dalam muhafahoh, santri dibiasakan melafalkan teks arab dengan benar dan menyimak dengan baik, di samping melatih daya ingat.

\section{Kegiatan Pembelajaran Tambahan}

Kegiatan pembelajaran tambahan dilaksanakan di luar jadwal pelajaran inti, yaitu pada malam hari. Pembelajaran tambahan tampak jelas pada jadwal harian santri. Kegiatan pembelajaran tambahan ini dilakukan sebagai penguatan keterampilan santri dalam membaca kitab kuning, terutama kegiatan khusus berupa sorogan. Kegiatan sorogan ini sangat efektif dalam memperkuat ketrampilan santri dalam praktek kebahasaan terutama aspek gramatika (nahwu dan shorof), di samping juga keterampilan berbicara dan membacanya (pemahaman).

Pada kegiatan khusus sorogan, santri dituntut untuk melakukan telaah terlebih dahulu secara 
mandiri dan mendalam terhadap teks kitab kuning yang akan dibacanya, baik telaah aspek kebahasaan, makna, maupun penjelasannya. Hal tersebut tidak dapat dihindarkan karena pada kegiatan sorogan, setelah santri membaca teks arab gundul tuntas dengan tarkib dan maknanya berikut penjelasannya, ustadz akan mengajukan beberapa pertanyaan terkait pembacaan kalimat (nahwu dan shorf) dan penjelasan materinya. Jawaban santri terhadap pertanyaan-pertanyaan ustadz harus berdasarkan argumen yang merujuk pada kitab kuning yang digunakan dalam pembelajaran sebagai referensinya.

Selain sorogan, kegiatan pembelajaran tambahan yang sangat efektif memperkuat kemampuan berbahasa santri adalah kegiatan khusus syawir atau diskusi. Pada kegiatan khusus syawir, santri dituntut telah melakukan telaah terhadap materi yang akan didiskusikan. Materi tersebut bersumber dari salah satu kitab yang memang digunakan dalam pembelajaran inti. Telaah tersebut bisa jadi telaah mendalam dalam kitab yang dimaksud atau telaah berupa upaya membandingkan materi yang sama dengan kitab yang lain. Sebagai contoh, materi yang akan didiskusikan adalah bab Sholat yang ada pada kitab Fatkhul Qorib. Maka santri dapat memperkaya wawasannya terkait materi Sholat dengan tidak hanya menelaah kitab Fatkhul Qorib saja, tetapi juga menelaah kitab fiqih yang lain. Misalnya, kitab Sulam Taufiq, Yaqut, atau Fatkhul Muin. Dalam hal ini tentu kompetensi membaca (memberi makna dan menelaah) kitab kuning santri harus sudah baik, karena teks kitab tersebut tidak akan terbaca oleh santri, jika tidak punya kompetensi membaca.

\section{Kegiatan Pembelajaran Bersama-sama (semacam kuliah umum)}

Kegiatan ini diasuh langsung oleh kiai. Kegiatan ini meliputi dua sesi. Sesi pertama adalah pelajaran Bahasa Arab. Tujuan utama pembelajaran Bahasa Arab adalah pengayaan kosa kata dan penguatan kemampuan tata bahasa Arab santri. Keterampilan berbahasa yang diasah pada sesi ini adalah berbicara (melafalkan kata dengan benar), menyimak, dan menulis (menyusun kalimat). Pola pembelajaran yang diterapkan oleh Kiai adalah dengan melontarkan sebuah kosa kata dalam bahasa Arab kemudian santri diminta menyusun kalimat berdasarkan kosa kata tersebut. Dalam pola ini, tentu kemampuan menulis (menyusun kalimat dalam bahasa Arab) santri terasah. Selain pola itu, pola lain yang juga diterapkan adalah kiai membacakan sebuah kalimat hikmah dalam bahasa Arab secara berulang-ulang dan santri diminta menirukan berkali-kali sampai dirasa oleh kiai santri-santri tersebut hafal, baru kemudian kiai menuliskan kalimat tersebut di papan tulis. Pada proses ini, kemampuan menyimak santri dilatih. Setelah proses tersebut, kiai mengajukan beberapa pertanyaan terkait nahwu dan shorfnya. Pada bagian ini, tentu keterampilan berbicara santri yang kemudian diasah.

Sesi kedua adalah pengajian kitab Maroqil Ubudiyah. Pada kegiatan ini, santri senior (santri mahasiswa dan tertentu) disuruh membaca teks kitab dihadapan santri-santri lain dan didampingi kiai. Santri lain dan kiai menyimak dan menuliskan bacaannya. Jika bacaan (lengkap dengan tarkib) atau terjemahan yang dibaca oleh santri tersebut salah, kiai langsung membenarkan.

\section{Kegiatan Pembelajaran Mandiri}

Kegiatan pembelajaran mandiri merupakan kegiatan yang tidak terjadwal dan dilaksanakan oleh masing-masing santri secara mandiri. Kegiatan pembelajaran mandiri ini meliputi telaah terhadap materi pelajaran, telaah materi untuk persiapan kegiatan sorogan, hafalan nadhom maupun juz Amma secara mandiri (sebelum kemudian disetorkan), dan telaah materi untuk kegiatan diskusi.

Kegiatan mandiri ini tidak hanya dilaksanakan santri secara individual, tetapi dapat juga dilaksanakan secara berdua, bertiga, atau mungkin berkelompok dengan beberapa anggota. Sebagai contoh, sebelum santri menghafal di hadapan ustadz, biasanya santri meminta kawannya untuk mendengarkan (menyimak) hafalannya. Atau sebelum santri masing-masing maju pada kegiatan sorogan, biasanya santri meminta kawannya untuk mendengarkan bacaan, dan mengoreksi kesalahannya.

Pendidikan literasi pada pembelajaran kitab kuning secara otomatis berintegrasi dengan lima metode pembelajaran tersebut menjadi kombinasi yang apik tanpa memandang mana yang membawa dan dibawa. Melalui kombinasi ini (Pendidikan literasi pada pembelajaran pesantren) terlihat ada dua pasang keterapilan berbahasa yang muncul dari empat keterampilan berbahasa yang ada yaitu 
menyimak-menulis dan membaca-berbicara.

Secara keseluruhan, praktek pembelajaran kitab kuning pada MDTA al Umami menggunakan bahasa Indonesia sebagai bahasa pengantarnya. Karena itu, kompetensi bahasa Indonesia juga secara otomatis dilatih. Sedangkan kompetensi bahasa menjadi kompetensi utama yang diperlukan sebab pembelajaran ini referensi utama yang digunakan adalah semua kitab yang ditulis dengan menggunakan aksara Arab dan berbahasa Arab.Maka keterampilan berbahasa di sini meliputi keterampilan berbahasa Arab dan keterampilan berbahasa Indonesia. Karena dalam proses pembelajaran, guru menggunakan bahasa Indonesia sebagai bahasa pengantarnya, sementara kitab pegangan dan referensi yang digunakan keseluruhan menggunakan bahasa Arab,maka, pada proses pembelajarannya akan banyak terjadi penerjemahan.

Keterampilan berbahasa Arab dalam pembelajaran kitab kuning meliputi menyimak, berbicara, membaca, dan menulis. Menyimak dalam hal ini berkaitan dengan menyimak dalam arti mendengarkan ucapan dalam bahasa Arab dan bahasa Indonesia, dan menyimak dalam arti menyerap infromasi berkaitan dengan materi pembelajaran. Berbicara dalam pembelajaran kitab kuning, bukanlah berbicara menggunakan bahasa Arab sebagai bahasa komunikasi, tapi lebih pada berbicara sebatas mengungkapkankan kata-kata dalam bahasa Arab. Sedangkan membaca dalam hal ini meliputi membaca (dengan pelafalan yang benar), membaca (menerjemahkan) dan membaca dalam arti memahami maksud dari teks. Sementara menulis, dalam pembelajaran kitab kuning adalah menulis dalam arti menuliskan kembali makna dan penjelasan guru, baik menggunakan aksara Arab pegon maupun menggunakan aksara latin. Termasuk dalam keterampilan menulis adalah pembelajaran menyusun kalimat dengan menggunakan bahasa Arab. Sedangkan menulis dalam arti menyampaikan gagasan atau ide dengan menggunakan bahasa Arab belum terlaksana.

Dua pasang keterampilan berbiacara di atas tidaklah menyalahi hukum dasar dari keterampilan berbiacara yakni antarketerampilan tidak bisa saling mendahuli sehingga urutannya tidak berubah.Secara hakiki 4 keterampilan berbicara tetap menduduki kedudukannya masing-masing tanpa perubahan (hal ini karena secara pemerolehan keterampilan sudah dimiliki oleh santri secara runut di awal pendidikannya) hanya saja dua pasang ketarampilan yang dimaksud disini adalah dampak dari penggunaan metode pesantren.

Hal ini terlihat pada metode "maknani" santri dituntut memiliki keterampilan menyimak yang tinggi untuk mendengarkan pembacaan Kiyainya dan dituntut memiliki keterampilan menulis yang cakap (menulis huruf pegon) sehingga dapat menuliskan makna yang dibacakan oleh Kiyai secara cepat dan tepat.Sedangkan dalam metode sorogan santri dituntut memiliki keterampilan membaca yang mumpuni sehingga dapat memahami isi wacana (teks kitab yang dipelajari) secara optimal dan pada akhirnya santri juga dituntut untuk memiliki keterampilan berbiacara yang tinggi untuk dapat menjelaskan hasil pemahamannya terhadap kitab yang dipeljarinya di hadapan Kiyai (Sorogan).

Berdasarkan uraian di atas kombinasi pendidikan literasi dan metode pembelajaran di pesantren memiliki kelengkapan unsur literasi dengan kualitas kemahiran yang tinggi. Selain itu kombinasi ini dapat diterapkan di semua kitab dan semua materi. Secara gambalang dapat kita pahami bahwa pendidikan literasi dengan metote pembelajaran pesantren memiliki kemungkinan yang besar untuk dapat diterapkan di pendidikan formal khususnya dalam pembelajaran bahasa tentu dengan persiapan dan perhitungan yang matang.

\section{PENUTUP}

Literasi pada pembelajaran kitab kuning yang notabennya menggunakan teknik pembelajaran khas pesantren memiliki kelengkapan unsur pembelajaran literasi dan kualitas yang tinggi. Hal ini terlihat dengan dipenuhinya kegiatan pembelajaran dengan empat keterampilan berbicara yang menjadi fokus utama pembelajaran literasi yang terintegrasi dalam lima metode pembelajaran khas pesantren. Literasi pada kitab kuning tidak terikat mutlak pada jenis materinya sehingga memungkinkan untuk bisa diterapkan pada pembelajaran umum khususnya pembelajaran bahasa yang ada di STKIP Nurul Huda.Penerapanliterasi untuk pembelajaran bahasa ini tentunya memerlukan penganalisaan 
yang mendalam agar pemelihan materi dapat dilakukan secara tepat.

Ada kemungkinan kombinasi pembelajaran ini dapat dikembangkan menjadi metode pembelajaran dan dapat kita singkat dengan MPLP (Metode Pembelajaran LiterasiPontren). Kemungkinan ini perlu dibuktikan dan diupayakan dalam bentuk pengadaan analisa mendalam berupa penelitian-penelitian lanjutan.Bagi dosen dan mahasiswa di lingkungan STKIP Nurul Huda dihimbau untuk melakukan penelitian lanjutan dengan dasar pikiran yakni berbasis pondok pesantren dalam kegitan pembelajaran di prodi masing-masing.

\section{UCAPAN TERIMAKASIH}

Ucapan terima kasih kami sampaikan kepada Pemerintah, khususnya SimlitabmasRistekdikti yang telah memberikan kesempatan untuk melakukan penelitian Dosen Pemula dengan memberikan dana hibah PDP kepada kami berdasarkan surat perjanjian dengan nomor kontrak No:2138/SP2H/LT/K2/KM/2018, tanggal 12 April 2018. Kami juga menyampaikan terima kasih kepada STKIP Nurul Huda Sukaraja, khususnya LPPM STKIP Nurul Huda Sukaraja yang telah mendukung dan mendampingi kami dalam proses menyelesaikan laporan penelitian sesuai dengan Surat Perjanjian Pelaksanaan Hibah Penelitian dengan Nomor:011/STKIP-NH/LPPM/VIII/2018.

Ucapan terima kasih juga kami sampaikan kepada Bapak Imam Busyro selaku kepala Madrasah Diniyah Takhasus Al Umami dan Bapak Zen Muttakin selaku pengasuh asrama Al Umami yang telah memberikan izi kepada kami untuk melaksanakan penelitian di unit yang dipimpinnya di bawah naungan Yayasan Pondok Pesantren Nurul Huda. Ucapan terima kasih juga kami sampaikan kepada ustadz-ustadz Madrasah Diniyah Al Umami yang telah bersedia menjadi nara sumber penelitian kami serta pihak-pihak yang telah mendukung terlaksananya penelitian ini.

\section{DAFTAR PUSTAKA}

Abidin, Y., Mulyati, T. \& Yunansah, H. (2017). Pembelajaran Literasi: Strategi Meningkatkan Kemampuan Literasi Matematika, Sains, Membaca, dan Menulis. Jakarta: Bumi Aksara.

Antoro, B. (2017). Gerakan Literasi Sekolah, dari Pucuk Hingga Akar, Sebuah Refleksi. Jakarta: Dirjen Pendidikan Dasar dan Menengah Kementrian Pendidikan dan Kebudayaan.

Azra, A. (2001). Pendidikan Islam Tradisional dan Modern Menuju Millenium Baru. Bandung: Mizan.

Bruinessen, M. V.(2012). Kitab Kuning, Pesantren, dan Tarekat. Yogyakarta: Gading Publishing.

Gay, L. R, Mills, Geoffer E \& Airasian, Peter W. (2012). Educational Research: Competencies for Analysis and Applications. Boston: Pearson education, Inc.

Kern, R. (2000). Literacyand Language Teaching. Oxfort: Oxfort University Press.

Mardiansyah, D. (2017). Pesantren Transformatif Transmigran, Studi Kasus Pondok Pesantren Nurul Huda Sukaraja. Tesis. UIN Raden Fatah Palembang. Tidak dipublikasikan.

Matraji, A. U. (2008). 'Reinveinting' Kitab Kuning dalam Tradisi Pesantren. Jurnal Mihrab, 2(2), 92-115.

Prastowo, A. (2011). Memahami Metode-metode Penelitian: Suatu Tinjauan Teoretis dan Praktis. Yogyakarta: Ar Ruz Media.

Raharjo, M. D. (1985). Pergulatan Dunia Pesantren. Jakarta: P3M.

Tilaar, H.A.R., Paat, J. Ph., \& Paat, L. (2011). Pedagogik Kritis: Perkembangan, Substansi, dan Perkembangannya di Indonesia. Jakarta: Rieneka Cipta.

Wahid, M., dkk. (1999). Pesantren Masa Depan. Bandung: Pustaka Hidayah.

Wells, G. (1987). Apprenticeship in literacy. Interchange, 18(1-2), 109-123. https://doi.org/10.1007/BF01807064 